\title{
Thomas More and the Defence of the Religious Orders in Henry VIII's England
}

\author{
Martin Heale (i) \\ Department of History, University of Liverpool, Liverpool, UK \\ Email: mrvheale@liverpool.ac.uk
}

\begin{abstract}
Much has been written about Thomas More's alleged monastic vocation and spirituality, but rather less about his views on the religious orders of his day. This article argues that a consistent position towards contemporary English monasticism can be discerned across More's (highly varied) oeuvre and in his personal connections with religious houses. He was an enthusiastic supporter of strictly observant monasticism throughout his career, but seems to have looked much more critically upon other branches of the religious orders in early Tudor England (which comprised the large majority). This orientation was shared with some other English humanists, but clashed with the position of Erasmus who held no special regard for strictly observant monasteries. More's misgivings about general monastic standards in the realm held a wider significance, in view of his status as the most prolific and influential polemicist writing in support of the early Tudor church. The defence of the religious orders in the controversialist works that More wrote and oversaw in the later 1520s and early 1530s was distinctly lukewarm, and even at times evasive. Partly as a result, the mounting evangelical and anticlerical attacks on English monasteries in these years went largely unanswered.
\end{abstract}

Like many of his contemporaries, Thomas More took a close interest in the monastic life. As a young man he dwelled in or near the London Charterhouse for a period of four years. His earliest writings included the light-hearted poem A merry jest how a serjeant would learn to be a friar (c. 1509). ${ }^{1}$ Monastic values, and particularly the common life, feature prominently in More's Utopia. His polemical writings, from the 'Letter to a monk' (1519-20) to his later works opposing anticlerical and evangelical critiques of the church and 'traditional religion', had plenty to say about monasticism

\footnotetext{
${ }^{1}$ For recent commentary on this work, see T. Betteridge, Writing faith and telling tales: literature, politics and religion in the works of Thomas More (Notre Dame, IN, 2013), pp. 10-14.

(c) The Author(s), 2021. Published by Cambridge University Press. This is an Open Access article, distributed under the terms of the Creative Commons Attribution licence (http://creativecommons.org/licenses/by/4.0/), which permits unrestricted re-use, distribution and reproduction, provided the original article is properly cited.
} 
and its contemporary practitioners. In the early 1530s, there frequently took place within More's social circle 'merry talkings' regarding the secular clergy and the religious orders - 'of their living, and of their learning, and of their livelihood too; and whether themselves were such as it were better to have them or lack them; and then, touching their livelihood, whether it might lawfully be taken from them or not'. ${ }^{2}$ He himself adopted various quasi-monastic practices in his devotional life, including daily regimes of prayer and a hair shirt. And as More faced his final reckoning with Henry VIII, he drew inspiration from Richard Reynolds of Syon and the three Carthusian priors executed on 4 May 1535, whose fortitude he admiringly ascribed to the strict and penitential life they followed. ${ }^{3}$

The monastic life has also loomed large in several historians' interpretations of the interior world of Thomas More. For Geoffrey Elton and Richard Marius, More was a failed monk who remained tormented by his inability to conquer his sexuality and embrace his calling to the celibate religious life, and found true peace only during his enforced confinement in the Tower. ${ }^{4}$ Other scholars have posited that monastic spirituality was central to More's mindset, while disagreeing about the particular focus of this influence. For Germain Marc'hadour, Thomas More's piety can best be labelled 'Franciscan', whereas James McConica and Eamon Duffy have identified Carthusian and, in particular, Bridgettine influences as central to More's spirituality. ${ }^{5}$ These rival characterizations partly reflect the various claims of Thomas More's early biographers regarding an alleged monastic vocation - with Nicholas Harpsfield suggesting that More contemplated joining the Carthusian order, and both Thomas Stapleton and Cresacre More asserting that he was strongly attracted to the Franciscans. ${ }^{6}$

Thomas More's supposed calling to the religious life has come under question in more recent scholarship. ${ }^{7}$ It has been pointed out that William Roper,

\footnotetext{
${ }^{2}$ Various editors, The complete works of St Thomas More (15 vols., New Haven, CT, 1963- ) (hereafter (WTM), IX, p. 79:9-21.

${ }^{3}$ W. Roper, The lyfe of Sir Thomas More, knighte, ed. E. Hitchcock (Early English Text Society, original series, vol. 197, London, 1935), pp. 25-6, 48-9, 80-1, 99.

${ }^{4}$ G. Elton, 'The real Thomas More?', in G. Elton, Studies in Tudor and Stuart politics and government, III (Cambridge, 1983), pp. 344-55; R. Marius, Thomas More (London, 1984), pp. xxii-iv, 34-43, 465, $490-1$.

${ }^{5}$ G. Marc'hadour, 'Thomas More's spirituality', in R. Sylvester, ed., St Thomas More: action and contemplation (New Haven, CT, and London, 1972), pp. 123-59; J. McConica, 'The patrimony of Thomas More', in H. Lloyd-Jones, V. Pearl, and B. Worden, eds., History and imagination: essays in honour of H. R. Trevor-Roper (London, 1980), pp. 56-71; E. Duffy, 'The spirituality of John Fisher', in B. Bradshaw and E. Duffy, eds., Humanism, reform and the Reformation: the career of Bishop John Fisher (Cambridge, 1989), pp. 205-31, at p. 223.

${ }^{6} \mathrm{~N}$. Harpsfield, The life and death of Sir Thomas Moore, knight, sometimes lord high chancellor of England, ed. E. Hitchcock and R. Chambers (Early English Text Society, original series, vol. 186, London, 1932), pp. 17-18, 205; T. Stapleton, The life and illustrious martyrdom of Sir Thomas More, ed. E. Reynolds, trans. P. Hallett (London, 1966), p. 8; C. More, The life of Sir Thomas More, ed. J. Hunter (London, 1828), pp. 25-6.

${ }^{7}$ See, in particular, J. Guy, Thomas More (London, 2000), pp. 21-41; and C. Barron, 'Thomas More, the London Charterhouse, and Richard III', in H. Kleineke, ed., Parliament, personalities and power (Woodbridge, 2011), pp. 203-14.
} 
More's earliest biographer, gave no indication that his subject considered entering a monastery, whereas another well-informed contemporary observer, Erasmus (in his 1519 letter to Ulrich von Hutten), reported that More had been drawn to the secular priesthood. ${ }^{8}$ Nor does Thomas More's sojourn at the London Charterhouse necessarily imply the testing of a vocation, as it was not especially unusual for laypeople to dwell within a monastery precinct in the early sixteenth century. ${ }^{9}$ Moreover, as Caroline Barron has argued, More's early biographers had good cause to emphasize his monastic influences and connections. Their principal concern was to demonstrate that More, a married layman whose opposition to Henry VIII was not so unambiguously in support of papal supremacy as that of other Henrician victims, was indeed a true and saintly martyr. Presenting their subject as strongly drawn to a monastic existence was an effective way to underline his sanctity of life. The hagiographical dividends, by the mid-sixteenth century, of associating More with the London Carthusians - widely venerated in Catholic circles by this date - are also clear enough. ${ }^{10}$ It is noteworthy that both Harpsfield and Stapleton took pains to explain why More did not embrace the contemplative life, with the latter speculating that he may have been put off by (what Stapleton regarded as) the lax standards of observance prevalent in religious houses at the time. By depicting his subject as living 'almost the life of a monk', and claiming that he even exceeded most monastic practitioners of the day in the roughness of his hair shirt, Stapleton implied that More would likely have pursued a religious vocation had he lived in a suitable (Counter-Reformation) environment. ${ }^{11}$

The purpose of this article is not to revisit debates on the place of monasticism in More's spirituality or vocation, but rather to pursue a connected and less well-explored theme: Thomas More's views towards the religious orders in early Tudor England. There are a number of potential benefits to such a study. More's attitude towards the monastic ideal can be illuminated by an analysis of his position towards the concrete manifestations of that ideal in his midst. His writings on the religious orders also provide an interesting case-study of the degree of consistency in More's religious thought over the course of his career, and (a much contested topic) between his early humanist and later controversialist writings. They can equally shed light on the extent of Erasmus's influence on More's thinking, since (it will be argued) the two writers held rather different views towards the strictly observant branches of the religious orders. This article will also explore the wider implications of Thomas More's attitude towards the monasteries of early sixteenth-century England, which was by no means wholly enthusiastic. During the later 1520 s and early 1530 s - a moment when the role and reputation of the realm's religious houses were coming under intense scrutiny - he was the most active and influential

\footnotetext{
${ }^{8}$ Various editors, The collected works of Erasmus (Toronto, ON, 1974- ) (hereafter CWE), VII, Ep. 999:149-55. See also CWTM, XV, p. 202:21-2.

${ }^{9}$ See also McConica, 'Patrimony of Thomas More', p. 59.

${ }^{10}$ Barron, 'Thomas More', pp. 210-11; A. Dillon, The construction of martyrdom in the English Catholic community, 1535-1603 (Abingdon, 2002), pp. 52-62. See also Harpsfield, Life, p. 210.

${ }^{11}$ Harpsfield, Life, pp. 17-18, 205; Stapleton, Life, pp. 8-9, 62-3, 69-70, 89.
} 
apologist for the English church. Yet More's defence of the monasteries of his day was decidedly guarded, and there are signs that his ambivalent attitude towards the religious orders was held by others among the conservativeminded educated elites of early Tudor England. As a result, England's monasteries would receive relatively little support from this quarter when the Henrician assault on the religious orders began in the mid-1530s.

An impression of Thomas More's standpoint towards the religious orders of his day may first be sought in the surviving evidence for his personal dealings with monks, friars, and nuns. In particular, he maintained demonstrably close ties with each of the three orders associated with strictly observant monasticism in early Tudor England: the Carthusians, the Bridgettines of Syon, and the Observant Franciscans. ${ }^{12}$ The four years that More spent living in (or, according to Cresacre More, near) the precinct of the London Charterhouse must have brought special familiarity with Carthusian life and practices. It is likely that he would have attended services in the conventual church, and Cresacre More described him as 'frequenting daily their [the monks'] spiritual exercises' ${ }^{13}$ More's 'Letter to a monk' indicates a personal acquaintance with the recipient, apparently an inmate of the London Charterhouse; and his one-time confessor, John Bouge, subsequently became a Carthusian at Axholme Priory (Lincolnshire). More is also known to have been in close contact in the early 1530s with two monks of Sheen Charterhouse, who came to his house at Chelsea to discuss Elizabeth Barton. ${ }^{14}$

There is at least as much, if not more, evidence for Thomas More's regular interactions with the Bridgettine abbey of Syon. From his exculpatory letter to Thomas Cromwell in the spring of 1534 regarding Elizabeth Barton, it appears that More was a regular visitor to Syon Abbey. He related that the subject of the Nun of Kent arose during one such routine visit, when he was 'talking with diverse of the Fathers together' at the grate where the Syon brothers could speak to laypeople. On their request, he later met with Barton herself in a chapel within the abbey precinct. More also records that he spoke with some of the community about Barton '[w]hen I came again another time to Syon, on a day in which there was a profession'. ${ }^{15}$ His attendance at this important event in the life of the monastic community implies a close interest in the abbey's affairs. More was also well acquainted with Richard Whitford of Syon, from the latter's days as chaplain to Bishop Fox of Winchester. ${ }^{16}$

\footnotetext{
${ }^{12}$ For an introduction to the various manifestations of strictly observant religious life in late medieval Europe, see J. Mixson and B. Roest, eds., A companion to observant reform in the late middle ages and beyond (Leiden, 2015).

${ }^{13}$ More, Life, p. 25. Thomas More's reference in his Apology to the length of matins in charterhouses also suggests familiarity with their services: CWTM, IX, p. 103:11-17.

${ }^{14}$ CWTM, XV, p. 202:18-21; Guy, Thomas More, p. 34; E. Rogers, ed., The correspondence of Sir Thomas More (Princeton, NJ, 1947), no. 197:188-98.

${ }^{15}$ Rogers, ed., Correspondence, no. 197: 120-42, 198-205; Roper, Lyfe, pp. 60-1.

${ }^{16}$ Roper, Lyfe, p. 8. See also CWE, II, Ep. 191.
} 
Thomas More seems equally to have enjoyed a certain level of familiarity with the Observant Franciscans. Two members of the order-Richard Risby and Hugh Rich, both of whom were subsequently executed on account of their association with Barton - are known to have made visits to More's house in Chelsea. Risby, at that time based in the Observant friary in Canterbury, lodged with More one night around Christmas 1532 during which visit the subject of the Nun of Kent was broached. Rich was reported to have spoken with him about Barton at More's residence on two occasions, and again in the garden of the Franciscan friary at Richmond. ${ }^{17}$ According to Thomas Stapleton, More was also acquainted with Katherine of Aragon's confessor, Alphonso de Villa Sancta, a Spanish friar stationed in the Observant Franciscan community at Greenwich. ${ }^{18}$ He seems, too, to have taken an interest in the Franciscan nuns, dedicating his Life of Pico to Joyce Lee on her entry into a house of Poor Clares. ${ }^{19}$

Notwithstanding the periodic efforts of scholars to press Thomas More's special spiritual affinity with a single one of these three orders - with, for instance, Elton privileging the Carthusians, McConica the Bridgettines, and Marc'hadour the Franciscans - the evidence of his personal and institutional connections suggests that he was drawn to all three. Furthermore, in his close interaction with the strictly observant wing of the religious orders More was by no means alone among early sixteenth-century English humanists. John Colet built a retreat for his old age within the precinct of Sheen Charterhouse, which was later used by Reginald Pole and Thomas Starkey. According to his early biographer, Ludovico Beccadelli, Pole had also been educated at Sheen as a boy. ${ }^{20}$ Richard Pace dwelt for several months at Syon Abbey, where he was joined for a time by Robert Wakefield. Meanwhile, the Anglo-Scottish humanist, Alexander Barclay, himself became an Observant Franciscan at some point in the 1520s, after a spell as a Benedictine monk at Ely. ${ }^{21}$

If Thomas More's personal connections with Carthusian, Bridgettine, and Observant Franciscan communities in and around London are well attested, we might note that evidence for his interactions with religious houses of other orders is much more elusive. It has been argued that the major Benedictine monasteries of pre-Reformation England were important centres of observant reform and humanist learning. ${ }^{22}$ Yet, interestingly, Thomas More is not known to have maintained particularly close relations with houses of black monks. He is likely to have had some acquaintance with the community at Westminster Abbey, and in his Apology commented favourably on the

${ }^{17}$ Rogers, ed., Correspondence, no. 197: 40-119.

18 Stapleton, Life, p. 35.

${ }^{19}$ Guy, Thomas More, pp. 37-8.

${ }^{20}$ CWE, VIII, Ep. 1211:404-11; T. Mayer, Thomas Starkey and the commonweal: humanist politics and religion in the reign of Henry VIII (Cambridge, 1989), p. 97; T. Mayer, Reginald Pole: prince and prophet (Cambridge, 2000), pp. 47-9.

${ }^{21}$ C. Curtis, 'Pace, Richard (1483?-1536)', ODNB; J. Woolfson, 'Wakefield, Robert (d. 1537/8)', ODNB; N. Orme 'Barclay, Alexander (c. 1484-1552)', ODNB.

22 J. Clark, 'Humanism and reform in pre-Reformation English monasteries', Transactions of the Royal Historical Society, 6th series, 19 (2009), pp. 57-93. 
generous almsgiving provided by that monastery. ${ }^{23}$ It may be, however, that the Benedictine community with which More maintained closest links was Canterbury Cathedral Priory. Cresacre More asserted that his greatgrandfather's two years as a student at Oxford were spent at Canterbury College, the study house of that monastic community. As Caroline Barron has noted, the fact that More's patron was Archbishop Morton of Canterbury - who had the right to nominate secular scholars at the college makes this a plausible claim. ${ }^{24}$ More appears to have maintained some contact with the Canterbury community in later life, since in 1530 he was granted admittance to the priory's confraternity. Germain Marc'hadour inferred from this grant that More had been a 'great benefactor' to the cathedral priory, but this is far from certain. His admission as a confrater may equally have resulted from a relatively modest act of patronage, or have been the product of an enterprising attempt by the Canterbury brethren to revive or solidify their house's connections with the present lord chancellor. ${ }^{25}$ We might also note that More does not seem to have corresponded with any of the Canterbury monks connected with Elizabeth Barton, or he would presumably have acknowledged this in his frank and detailed letter to Cromwell concerning his communication 'with diverse that were of acquaintance with the lewd Nun of Canterbury'. ${ }^{26}$

Whatever the precise nature of Thomas More's association with Canterbury Cathedral Priory, there is little indication that he established close links with any other Benedictine houses. Two of his surviving letters, dated to 1518 and 1523, were written at Abingdon, but it is unclear whether this denotes the Benedictine abbey or the town. ${ }^{27}$ For more than fifteen years, More was the recipient of a corrody from Glastonbury Abbey to the annual value of five pounds, but this grant does not imply a personal relationship with the monastic community. The crown enjoyed the right to nominate its own appointees for a corrody at Glastonbury, and More was the beneficiary of one such award by Henry VIII on 1 June 1519. After his death, this grant was swiftly transferred to Thomas Cromwell 'according unto the pleasure and commandment of the king's highness. ${ }^{28}$ In his Apology (1533), More himself asserted that he had 'no very great part of my living by the clergy', and indeed there is no sign that he was a regular beneficiary of monastic grants and fees, either

\footnotetext{
${ }^{23}$ CWTM, IX, p. 104:19-24.

${ }^{24}$ More, Life, p. 18; Barron, 'Thomas More', p. 10. This connection is also accepted in S. Baker House, 'More, Sir Thomas [St Thomas More] (1478-1535)', ODNB.

${ }^{25}$ P. Collinson, N. Ramsay, and M. Spark, eds., A history of Canterbury Cathedral (Oxford, 1995), p. 147; Marc'hadour, 'Thomas More's spirituality', p. 156n. For a fifteenth-century list of entrants to a monastic confraternity with details of the varied benefactions made, see M. Heale, Monasticism in late medieval England, c. 1300-1535 (Manchester, 2009), pp. 182-5.

${ }^{26}$ Rogers, ed., Correspondence, no. 197: 5-7.

${ }^{27}$ Ibid., nos. 60, 123 .

${ }^{28} \mathrm{~J}$. Brewer, J. Gairdner, and R. Brodie, eds., Calendar of the letters and papers, foreign and domestic, of the reign of Henry VIII (22 vols., London, 1864-1932), III(i), no. 280; The National Archives (TNA), SP 1/96, fo. 106r. See also I. Keil, 'Corrodies of Glastonbury Abbey in the later middle ages', Proceedings of the Somerset Archaeological and Natural History Society, 108 (1964), pp. 113-31.
} 
through the agency of the crown or individual religious houses. ${ }^{29}$ Otherwise, the extant evidence for his personal associations with the (non-strictly observant) religious orders relate to his public duties. For instance, More referred in his Dialogue concerning heresies (1529) to a visit he made to the abbey of Benedictine nuns at Barking as a young man, at the time of an episcopal inspection of newly discovered relics. He also presided over a number of legal cases involving monasteries as lord chancellor, and in this capacity came into contact - as he later remarked - with both good and remiss representatives of the religious life. ${ }^{30}$

This survey of Thomas More's known connections with religious houses in early Tudor England cannot produce decisive conclusions, owing to the uneven nature of the available evidence. It is, however, suggestive that so much of the surviving documentation for More's personal relations with monastic individuals and communities pertains to the three strictly observant orders operating in early Tudor England: the Carthusians, Bridgettines, and Observant Franciscans. He is likely to have maintained connections with religious houses of other orders, on both a personal and professional level. However, there is little sign - either in the records pertaining to More's life, or in any of the evidence thus far unearthed in royal or monastic archives - to indicate that he was on close terms with any such communities. As we shall see, this pattern of apparent allegiance is closely mirrored in More's writings, and thus appears to reflect a more general disposition towards the religious orders of his day.

\section{II}

Thomas More's most direct treatment of the monastic life and contemporary religious orders in his earlier writings can be found in his 'Letter to a monk. ${ }^{31}$ This Latin work circulated in manuscript in 1519 and was published in a pro-Erasmus miscellany the following year. The 'Letter to a monk' was written expressly to defend Erasmus against an attack on his scholarship and writings (especially his Novum instrumentum and Praise of folly), and on his lifestyle as a lapsed regular canon, by an unnamed monk generally identified as the Carthusian John Batmanson. ${ }^{32}$ This dispute, moreover, had a strong personal resonance for More: Erasmus had (or so he reported) written Folly at More's suggestion and while staying at his house; Batmanson was known personally to him; and the offending critique of Erasmus's life and work was apparently set out in a letter addressed to More himself. ${ }^{33}$

The 'Letter to a monk' has sometimes been contrasted with More's later writings, to illustrate perceived differences between Thomas More the

\footnotetext{
${ }^{29}$ CWTM, IX, p. 47:12-13.

${ }^{30}$ Ibid., VI, p. 222:1-35, IX, p. 49:16-31. Examples of Chancery cases involving religious houses coming before Chancellor More include: TNA, C1/607/19, C1/676/2, and C1/685/10. See also J. Guy, The public career of Sir Thomas More (Brighton, 1980), pp. 60, 69-70.

${ }^{31}$ CWTM, XV, pp. 198-311.

${ }^{32}$ D. Knowles, The religious orders in England (3 vols., Cambridge, 1948-59), III, p. 469; CWTM, XV, pp. xli-xlii; Barron, 'Thomas More', p. 212.

${ }^{33}$ CWTM, XV, p. 199:8-15.
} 
humanist' and Thomas More 'the religious polemicist'. For instance, Daniel Kinney, the most recent editor of the letter, found it difficult to reconcile More's 'energetic defence' of monasticism in his 'Letter to Bugenhagen' with the 'trenchant critique' of his retort to Batmanson. ${ }^{34}$ Meanwhile, for those who admire More as a defender of the church, the criticisms of monastic practices set out in the 'Letter to a monk' have seemed regrettable. David Knowles in particular evinced some embarrassment at this work, which he concluded was the result of the bewitching influence of Erasmus on More. ${ }^{35}$ Kinney similarly concluded that this 'may well be More's own most thoroughly Erasmian work'. ${ }^{36}$ The 'Letter to a monk' therefore raises questions about the consistency of Thomas More's oeuvre and the extent to which the influence of Erasmus permeated his early writings. An analysis of More's treatment of the religious orders in this tract, however, suggests that we should be wary of overplaying the degree to which his views and judgements regarding monasticism were shaped by Erasmus, or evolved over time.

There is no question that the 'Letter to a monk' has a distinctly Erasmian flavour. In his rebuttal of Batmanson's critique of Praise of folly, More rehearsed a number of the charges Erasmus had made against the religious orders of the day, often in very similar terms. Just as Erasmus had lampooned monks and friars for taking excessive pride in the petty rules and ceremonies of their orders, More lamented the disputes arising between religious orders 'on account of a different colour, or a differently cinctured robe, or some other trivial ceremony that is possibly not altogether contemptible, but is certainly an unworthy pretext for banishing charity!'. ${ }^{37}$ Just as Erasmus had derided elaborate monastic services, More ridiculed 'some of the rhythmical prayers with which some of your brethren suppose they put all of the saints in their debt every time that they honour their memory with such foolish jingles that not even a rogue trying his hardest to mock them could muster more foolish ones'. ${ }^{38}$ And just as Erasmus had censured those in religious orders for arrogantly considering themselves superior to others, More criticized regular clergy who 'conceive such a lofty self-image that they think they are walking in the heavens or that they themselves, perched on a sunbeam, look down from the heights on the general populace creeping like ants on the ground, and not only on the laity but also on the whole class of priests who live outside the cloister!' ${ }^{39}$

At certain points, More's letter also seems to pass critical comment on fundamental aspects of monastic observance. In response to Batmanson's attack on the mobility of Erasmus (as a professed regular canon), More questioned the inherent value of monastic stabilitas: '[a]s if it were the essence of holiness to stagnate forever and stay glued to one rock all the time like an oyster or

\footnotetext{
${ }^{34}$ Ibid., XV, p. xci.

${ }^{35}$ Knowles, Religious orders, III, p. 154.

${ }^{36}$ CWTM, XV, p. xliii.

${ }^{37}$ Ibid., XV, p. 278:4-7.

${ }^{38}$ Ibid., XV, p. 258:24-7.

${ }^{39}$ Ibid., XV, p. 278:7-12.
} 
sponge!! ${ }^{40}$ He further opined that the scholarly endeavours of Erasmus had borne more fruit for the church than monks accomplish over several years with their 'fasts or perfunctory prayers'. This statement, however, clearly reflects More's high view of the value of humanist learning rather than any disparagement of monks' intercession, since he also acknowledged that 'the misery of this world is substantially alleviated by your [i.e. monastic] pleading in its behalf. ${ }^{41}$ Indeed, More was careful to emphasize his profound respect for the professed religious:

I have no doubt at all that there is no good man anywhere who does not feel a great deal of heartfelt esteem for all religious orders, and certainly I myself have always regarded them not only with love but also with the utmost reverence, since it is my custom to honour the poorest man commended by virtue more than anyone distinguished for his riches or admired for an illustrious birth.

Consequently, he wished 'all other mortals to be deeply devoted to you and your orders, as your merits deserve. ${ }^{42}$

In the same way, More makes clear that his strong critique of Batmanson's writings and presumptions should not be equated with an attack on the Carthusian way of life per se. Warning of the dangers of spiritual pride, he urged his interlocutor to "place more hope in the Christian religion than you do in your own religious order', and cautioned that strict withdrawal from the world may not always be embraced for pure and spiritual motives. ${ }^{43}$ Yet although the monk was wrong to view his vocation as intrinsically superior to every other, it was nonetheless a 'splendid regimen' ${ }^{44}$ Indeed, a consistent theme of More's critique of Batmanson was that he had failed to live up to his order's laudable ideal. He should ensure that he has fully forsaken the world, rather than involving himself with religious controversies, scholarly debates, and scandal-mongering. Likewise, he should practise the humility on which his whole profession rested, rather than belittling other laudable forms of Christian living. ${ }^{45}$ It is also noteworthy that at no point did More accuse Batmanson or any other member of his order of impure or scandalous living.

Yet, if Thomas More expressed sincere respect for the Carthusians' contemplative vocation, he indicated that he held a still higher regard for the 'apostolic life' of the mendicants. Indeed, the warmest sentiments about the religious life in the 'Letter to a monk' were reserved for the Franciscans, with More opining that "no order (unless I am mistaken) is holier than this one'. ${ }^{46}$ This encomium - alongside his dedication of the Life of Pico to a Poor Clare nun; his allusions to the Franciscan order in Utopia; and the later (and

\footnotetext{
${ }^{40}$ Ibid., XV, p. 294:18-20. This was another distinctively Erasmian jibe: CWE, XXVII, p. 132.

${ }^{41}$ CWTM, XV, pp. 296:9-12, 276:9-10.

${ }^{42}$ Ibid., XV, pp. 274:31-276:6.

${ }^{43}$ Ibid., XV, p. 302:2-14.

${ }^{44}$ Ibid., XV, p. 264:13-14.

${ }^{45}$ Ibid., XV, pp. 262:17-264:24, 292:2-10.

${ }^{46}$ Ibid., XV, pp. 294:20-7, 300:23-302:2.
} 
contentious) claims of Thomas Stapleton and Cresacre More that he considered joining the order-have been taken to signal the Franciscan character of Thomas More's spirituality. ${ }^{47}$ It is worth emphasizing, however, that More's attraction to the grey friars seems to have been firmly directed towards their Observant branch - widespread and powerful in most parts of Western Europe by the early sixteenth century, but a relatively marginal presence in Tudor England. ${ }^{48}$

In the 'Letter to a monk', More relayed an anecdote regarding his clash in Coventry with a friar whom he pointedly described as belonging to 'that group of Franciscans who have not yet been reformed according to the Rule of St Francis'. ${ }^{49}$ This disparaging remark about the 'conventual' branch of the order (dominant in More's England) as unreformed and therefore not truly following their founder's rule, does not imply an undiscriminating admiration for the grey friars. Nor does the story that follows, with its standard anti-fraternal tropes depicting the friar in question as an ignorant preacher who deceived laypeople and hindered parochial ministry by offering easy routes to salvation. In his later polemical writings, More regularly singled out the Observant Franciscans for praise, generally alongside the other main representatives of strictly observant monasticism in early Tudor England, the Carthusians and the Bridgettines of Syon (see below).

In view of its target and polemical context, it was inevitable that Thomas More's 'Letter to a monk' would convey some critical sentiments towards monastic practitioners. His specific concern to defend Praise of folly also necessarily infused the work with Erasmian themes. Nevertheless, More's treatment of the religious orders in the 'Letter' was by no means fully consistent with his friend's own appraisal of the monastic landscape of the day. A good deal has been written about Erasmus's complex and evolving views on the religious life and vocation..$^{50}$ Much of his commentary on this topic, highlighting what he regarded as the prevalent monastic abuses of the day, was couched in general terms and not aimed at any particular religious order. Yet in contrast to Thomas More, Erasmus seems to have regarded the strictly observant branches of contemporary monasticism with some wariness. After all, his own community of Steyn was a member of the Chapter of Sion, a branch of the Augustinian canons influenced by the observant Windesheim Congregation. ${ }^{51}$ It was,

\footnotetext{
${ }^{47}$ Marc'hadour, 'Thomas More's spirituality', pp. 123-59; R. Coogan, “'From the chin upward, above St Francis": More, Tyndale and the Franciscans', in J. Day et al., eds., Word, church and state: Tyndale quincentenary essays (Washington, DC, 1998), pp. 217-27; D. Baker-Smith, 'Utopia and the Franciscans', in A. Cousins and D. Grace, eds., More's Utopia and the Utopian inheritance (Lanham, MD, 1995), pp. 37-52.

48 See K. Brown, 'The Franciscan Observants in England 1482-1559' (Ph.D. thesis, Oxford, 1986), for a useful overview of this topic.

${ }^{49}$ CWTM, XV, p. 284:13-14.

${ }^{50}$ Valuable overviews of this theme can be found in E. Rummel, 'Monachatus non est pietas: interpretations and misinterpretations of a dictum', in H. Pabel, ed., Erasmus's vision of the church (Kirksville, MO, 1995), pp. 41-55; and CWE, XXXIX, pp. 282-5.

${ }^{51}$ For the relationship between Windesheim and Sion, see R. Post, The modern devotion: confrontation with Reformation and humanism (Leiden, 1968), pp. 312-13; W. Scheepsma, Medieval religious
} 
therefore, this rigorist branch of monasticism with which Erasmus was most closely acquainted, and from which he had fled.

Erasmus's misgivings towards strictly observant forms of religious life were outlined in the first edition of his Enchiridion militis christiani (1503). Brethren who followed austere forms of observance, he asserted, were particularly prone to over-reliance on the rituals of their orders, and often failed to live up to their spiritual ideals:

But if we be allowed to admit the truth, do we not see that those monks who live the strictest lives place the highest religious perfection in ceremonies or a fixed recitation of the psalms or manual labour? But if anyone were to examine and question them about spiritual things, he would find very few who do not walk in the flesh. ${ }^{52}$

Erasmus developed this critique in Praise of folly (first published in 1511), whose bracing satire on contemporary monasticism was particularly directed at strictly observant branches of the religious life, and what was portrayed as their self-righteous obsession with the petty regulations of their orders. ${ }^{53}$ Erasmus's letter to 'Lambertus Grunnius', written in 1516 as part of his drive to secure papal dispensation from his monastic obligations, expressed even more starkly his concerns about how strictly observant monasticism was often practised. He here compared 'the great multitude of monasteries' where laxity had all but killed true religious life therein, with stringent houses that (like Steyn, in Erasmus's view) yet lacked 'the spirit of Christ'. The latter, he judged, 'are almost worse than the other', on account of their Pharisaic pride and harsh treatment of their inmates - "whipping boys to death every day' - merely for the sake of their rituals and to impress outsiders. To move, he opined, from one monastery to a stricter house or order (as canon law permitted) was to risk 'falling into yet harsher servitude. ${ }^{54}$

Erasmus was not dismissive of strictly observant monasticism in itself. He consistently emphasized to his critics that he opposed only bad monks rather than any particular form of religious life, ${ }^{55}$ and asserted - somewhat defensively - his close ties 'with those monasteries where religious discipline is most strictly observed'. ${ }^{56}$ Among those warmly commended by Erasmus for their pious living was the Benedictine Paul Volz (abbot of Hugshofen, part of the reformed Bursfeld Congregation), described in the preface to the 1518 edition of the Enchiridion as the 'peculiar glory of the true religious life'; and Jean Vitrier (the Observant Franciscan warden of St Omer), about whose life and character Erasmus wrote a

women in the Low Countries: the modern devotion, the canonesses of Windesheim, and their writings, trans. D. Johnson (Woodbridge, 2004), p. 13 and references.

${ }^{52}$ CWE, LXVI, p. 78. For a similar statement, in a much later work (the Apologia adversus rhapsodias Alberti Pii), see CWE, LXXXIV, p. 205.

${ }^{53}$ Ibid., XXVII, pp. 131-5.

${ }^{54}$ Ibid., IV, Ep. 447:622-54. This letter was published as part of Froben's Opus epistolarum edition in 1529 .

${ }^{55}$ See also Rummel, 'Monachatus non est pietas', pp. 44-8.

${ }^{56}$ CWE, XIII, Ep. 1805:297-303. 
glowing account in $1521 .^{57}$ Equally, a pious and learned Carthusian features (among a cast of less sympathetically drawn monks, friars, and nuns) in the Colloquies. ${ }^{58}$ However, Erasmus evidently harboured doubts about the inherent superiority of this branch of contemporary monastic life, to the consternation of his (many) observant critics. Indeed, a lack of overt enthusiasm towards strictly observant monasticism is a recurring theme in Erasmus's writings on the religious life - running from the first edition of the Enchiridion down to his Ecclesiastes (1535), in which he avowed that a humble pastor 'who performs his office correctly is to be preferred to many Carthusians and Bridgettines. ${ }^{59}$

Not only did Erasmus evince misgivings about strictly observant monasticism in general, but he also lacked Thomas More's earnest admiration for the Observant Franciscans. Erasmus was by no means implacably hostile towards this religious order. Aside from his admiration of Jean Vitrier, the colloquy 'The well-to-do beggars' (first printed in 1524) set out a highly sympathetic depiction of two Observant Franciscans from Basle, a religious community with which he was on good terms. ${ }^{60}$ Nor was Erasmus averse to broadcasting Observant critiques of their 'unreformed' rivals in the midst of his scholarly dispute with Henry Standish, the head of the English Conventual Franciscans. ${ }^{61}$ Yet it is worth noting that Erasmus's praise for Vitrier was precisely as an Observant Franciscan who acknowledged the shortcomings of his order's rigorist approach to the religious life. According to Erasmus's eulogy, Vitrier regarded a daily existence governed 'at the sound of a bell' to be 'a life for idiots', and regretted how religious men 'were often buried by ceremonies and petty man-made constitutions ${ }^{62}$ Certain of the critiques of fussy legalism in Praise of folly, moreover, were squarely aimed at the grey friars. ${ }^{63}$

Erasmus's criticism of the Observant Franciscans intensified in the final years of his life, partly in response to attacks on his writings by brethren of that order. ${ }^{64}$ The grey friars featured prominently as a target in Erasmus's

${ }^{57}$ Ibid., VI, Ep. 858, VIII, Ep. 1211:16-273. See also P. Bietenholz and T. Deutscher, eds., Contemporaries of Erasmus: a biographical register of the Renaissance and Reformation (3 vols., Toronto, ON, 1985-7), III, pp. 408-9, 417-18. Erasmus also admired the Observant Franciscan preacher, Dietrich Coelde: CWE, IX, Ep. 1347.

58 'The solider and the Carthusian' (1523): CWE, XXXIX, pp. 328-43. The introductory note to this colloquy by Craig R. Thompson (pp. 328-9) offers a nuanced evaluation of Erasmus's views towards the Carthusian order, as generally respectful but not uncritically so.

${ }^{59}$ CWE, LXVII, p. 384 (and see also pp. 367-8).

${ }^{60}$ Ibid., XXXIX, pp. 468-98, XVI, Ep. 2300:136-7. For other Franciscan communities with which Erasmus maintained friendly relations, see B. Roest, "Expectamus regnum franciscanum": Erasmus and his seraphic obsession', Collectanea Franciscana, 74 (2004), pp. 23-44, at pp. 29-30.

${ }^{61}$ CWE, XXXIII, pp. 286-90.

${ }^{62}$ Ibid., VIII, Ep. 1211:34-43. Similarly, the monk in the colloquy 'The soldier and the Carthusian' sets 'little store' by 'dress, food, little prayers, and other rites' and 'trivialities of this kind': ibid., XXXIX, p. 333:4-13.

${ }^{63}$ For instance, the references to the prohibition against touching money and to disputes over the hue of a habit: ibid., XXVII, pp. 131-2.

${ }^{64}$ For Erasmus's frustration about Observant Franciscan criticism of his writings, see (inter alia) ibid., XIV, Ep. 1967:142-5, 1968:37-53, XV, Ep. 2094:1-31, XVI, Ep. 2205:180-3, Ep. 2275, passim, and the discussion in Roest, "'Expectamus regnum franciscanum"'. 
published writings of the late 1520 s and early 1530 s - including the colloquies 'The sermon' (aimed specifically at an Observant Franciscan) and 'The seraphic funeral', and in his Apologia adversus rhapsodias Alberti Pii. ${ }^{65}$ His correspondence of this period also contains a number of unflattering remarks about the order. For instance, a 1528 letter to John Longland railed against the poor quality of contemporary monastic and mendicant life: 'And in those that are privileged with the name of the Observance, good God! How few there are in which you will observe the sincerity of the Christian Soul!' A missive the following year to Alfonso Valdés archly attributed the popular respect enjoyed by the Observant Franciscans to 'a certain appearance of piety'. ${ }^{66}$

Therefore, despite Thomas More's absorption of a number of Erasmus's critiques of the monastic life in his 'Letter to a monk', we can discern notable differences in the two men's orientation towards the religious orders of their day. More considered the strictly observant orders to be the most estimable and imitable contemporary representatives of the monastic ideal, whereas Erasmus judged them little or no better than other religious orders since their rigorist approach often tended in his view to legalism and harshness. No doubt these contrasting responses had much to do with the two men's personal encounters with this form of monastic life. Erasmus had experienced strictly observant monasticism first hand, and had found it "utterly repugnant to my mind and body alike'. ${ }^{67}$ By contrast, More had witnessed this form of religious life as an interested and sympathetic observer, and had been impressed by what he had seen. The relative scarcity (and, arguably, the high quality) of strictly observant monasticism in More's England may also have shaped his response. In any case, these divergent views towards contemporary religious orders - and the forms of piety and spirituality they represented - indicate the limits of Erasmus's influence on More and on his writings on the religious life, including the 'Letter to a monk'.

\section{III}

From the mid-1520s, Thomas More's literary output consisted increasingly of religious polemic. This phase of his career began with the Latin 'Letter to Bugenhagen' (written in 1526, but not published in More's lifetime), and greatly expanded following his commissioning in 1528 by Bishop Tunstal of London to respond in English to heretical writings. More was by some distance the most prolific writer in Henry VIII's England to counter the early evangelical challenge, with his English-language treatises alone comprising around a million words. ${ }^{68}$ The monastic life and the religious orders featured in several of his polemical works, including the 'Letter to Bugenhagen', the Dialogue concerning heresies (1529), The supplication of souls (1529), The confutation of Tyndale's

\footnotetext{
${ }^{65}$ CWE, XL, pp. 938-62, 996-1032, LXXXIV, p. 193.

${ }^{66}$ Ibid., XIV, Ep. 2037:226-8, XV, Ep. 2126:169-82 (and see also XVI, Ep. 2301:16-18).

${ }^{67}$ Ibid., II, Ep. 296:30-1.

${ }^{68}$ Rogers, ed., Correspondence, no. 160; B. Bradshaw, 'The controversial Sir Thomas More', Journal of Ecclesiastical History, 36 (1985), pp. 535-69, at p. 535.
} 
answer (1532-3), and The apology of Sir Thomas More, knight (1533).$^{69}$ It is noteworthy, however, that monasticism did not occupy a central position in any of More's polemical writings - and, perhaps for that reason, this dimension of his controversialist oeuvre has rarely attracted sustained attention from scholars. ${ }^{70}$

These apologetic works shared a common purpose in defending the early Tudor church against attack, but display some variation in genre and audience. The unpublished and Latin 'Letter to Bugenhagen' was aimed at a more restricted, elite readership. The Dialogue set out a refutation of various Lutheran ideas in the form of a dramatized conversation between More and a young man attracted to reformist teachings, ${ }^{71}$ while the Supplication and Confutation responded to specific works of evangelical polemic. In each of these English publications, More was writing for a general audience of any who might have encountered heretical messages. The Apology was a more delicate undertaking, serving as both a defence of More's record as lord chancellor, and a rebuttal of the Treatise concerning the division between the spiritualty and temporalty (1532). An anticlerical rather than an evangelical work, this treatise set out a wide-ranging critique of the clergy, written (anonymously) by the lawyer Christopher St German and published by the king's own printer, Thomas Berthelet. ${ }^{72}$ Yet, despite these differences in form and agenda, More's handling of the monastic life and the religious orders was highly consistent across his polemical writings, with similar themes and judgements recurring from treatise to treatise.

We can also observe a good deal of continuity in his treatment of this subject matter between his polemical works and his earlier writings. The contrast between More's handling of the religious orders in the 'Letter to a monk' and his later works is essentially one of emphasis and tone - a product of the major contextual and situational differences between these productions - rather than overall evaluation or orientation. As we have seen, the 'Letter to a monk' set its complaints and criticisms within an essentially favourable view of the monastic life, particularly its more strictly observant manifestations. Conversely, More's polemical works mounted a defence of the religious orders in early Tudor England, but without displaying uncritical admiration towards them. A certain ambivalence therefore runs through all of Thomas More's writings on contemporary monasticism.

Perhaps the most conspicuous common ground between More's early and later writings with regard to the monastic life can be found in his consistently warm response towards those religious orders associated with strictly

\footnotetext{
${ }^{69}$ All these volumes can be consulted in the Complete works of Thomas More editions.

${ }^{70}$ An important exception is M. Kaartinen, Religious life and English culture in the Reformation (Basingstoke, 2002). However, the thematic structure of this work means that More's writings on monasticism are not analysed holistically or fully contextualized.

${ }^{71}$ For a detailed account of the purpose, structure, and coverage of the Dialogue, see C. D'Alton, 'Charity or fire? The argument of Thomas More's 1529 Dyaloge', Sixteenth Century Journal, 33 (2002), pp. 51-70.

72 J. Guy, 'Thomas More and Christopher St German: the battle of the books', in A. Fox and J. Guy, eds., Reassessing the Henrician age: humanism, politics and reform, 1500-1550 (Oxford, 1986), pp. 95-120.
} 
observant monasticism in early Tudor England. In his Confutation of Tyndale's answer, More lauded the austere living of 'those good men' of the Charterhouse, and the proselytizing of observant friars - 'honest, godly, chaste, virtuous people' - in the New World. He also commented how no form of monastic life could please Tyndale, 'neither Greenwich, Syon, nor Charterhouse', with the implication that these houses sat at the pinnacle of observance in early Tudor England..$^{73}$ These three religious orders would be singled out again in More's Dialogue of comfort (1534) - a devotional rather than polemical work - with the Carthusians ('holy monks'), Bridgettines, and Franciscan nuns lauded for withdrawing contentedly from the world out of their love for God. $^{74}$

Alongside his unfettered praise for strictly observant religious orders, More's polemical writings echoed his 'Letter to a monk' by repeatedly emphasizing the inherent value of the monastic way of life. In his 'Letter to Bugenhagen', More expressed a very high estimation of the monastic calling: 'Religious orders have produced a great many men of extraordinary sanctity...[while] the purest segment of the Christian people have always been found in religious orders.' Their way of life was also certified by the great holiness of their original founders. Monastic living, More added, with its austerities and self-denial, followed Christ's teaching and example far more faithfully than the pampered and indulgent lives of its evangelical critics. ${ }^{75}$ The supplication of souls set out a robust defence of the friars' practice of begging and the endowments held by monastic houses. ${ }^{76}$ And in the Apology, More denied that the professed religious life was in any way inferior to the calling of secular priests, and asserted that Christian people were bound to show honour towards religious persons on account of their "holy profession of their godly state of living.' ${ }^{77}$

Yet notwithstanding the forthright defence of the monastic ideal running through More's polemical works, these publications were by no means unrestrained in their enthusiasm for contemporary religious orders. Just as he had written in his 'Letter to a monk' that monastic communities produced 'both wholesome and noxious herbs', ${ }^{78}$ More consistently acknowledged in his polemical works that both good and bad religious could be found in early Tudor England. In the Dialogue concerning heresies, he bemoaned how people pay little heed to the preaching of a good man, but 'let a lewd friar be taken with a wench, we will jest and rail upon the whole order all the year after'. Responding to evangelical arguments in favour of clerical marriage, he remarked in The supplication of souls that the worst sort [of religious] and such as now be slander of their order' would readily reproduce, while 'the good priests and good religious' would respect their vows and refuse to

\footnotetext{
${ }^{73}$ CWTM, VIII, pp. 125:34-126:14, 191:10-21, 163:12-21.

${ }^{74}$ Ibid., XII, pp. 276:20-277:5; and see also p. 80:1-2 for More's favourable view of strictly enclosed female orders.

${ }^{75}$ Ibid., VII, pp. 52-3.

${ }^{76}$ Ibid., VII, pp. 130:23-131:1, 138:31-139:13, 142:34-143:2, 214:28-215:13.

${ }^{77}$ Ibid., IX, pp. 62:24-63:14, 71:20-6.

${ }^{78}$ Ibid., XV, p. 290:1-3.
} 
marry. In a similar vein, he wrote in his Apology that as a royal officer he had loved and honoured good (secular and regular) clergy, while vigorously correcting 'those that were naught, noyous to good people, and slanderous to their own order'. ${ }^{79}$

Equally, the anecdotes and merry tales with which More enlivened his polemical writings portrayed a varied cast of virtuous and sinful monastics. For instance, the Dialogue concerning heresies featured the 'very good and godly company' of Franciscan nuns who received into religion Sir Roger Wentworth's daughter, following her miraculous healing at Our Lady of Ipswich; and also a fraudulent and immoral (Benedictine) prior of Leominster, who pretended his concubine to be a holy maid fed miraculously by angels. ${ }^{80}$ The recurring appearance of mendicants in More's tales - a throwback to his first literary efforts, and another common thread between his early and later writings ${ }^{81}$ - introduces to the reader a highly diverse cast of characters: a long-winded preacher rebuked by a 'poor wife of the parish'; a mendicant of good fame widely but potentially unfairly accused of sexual predation; and a poor friar who wisely preferred to embrace strict austerity of life rather than risk the ultimate fate of his soul. ${ }^{82}$

The cumulative effect of these statements and illustrations is a rather ambiguous appraisal of the quality of contemporary monasticism. More insisted that there were indeed 'good religious folk', ${ }^{83}$ and thus the blanket condemnation of monks, friars, and nuns by evangelical critics was unfair and unjustified. Yet, at the same time, his writings implied that there was no shortage of unfitting representatives of the monastic life in early Tudor England. This may in itself have been a fairly widely held view, and one which More perhaps wished to acknowledge to display even-handedness; but it is nonetheless noteworthy to find it so freely, frankly, and repeatedly asserted in polemical works in defence of the English church. The tepid nature of More's general endorsement of the religious orders occasionally comes across more explicitly. For instance, his defence of contemporary monastic observance in the Apology, in response to Christopher St German's critiques of the church, was decidedly underwhelming. Rather than praise present-day standards, More simply denied that there had been any notable decline in recent times, stating that the secular and regular clergy of his day lived 'muchwhat after such a good, meetly mean manner' as previous generations. Likewise, he did not directly contest St German's claims about widespread monastic laxity, but instead retorted that the majority of laypeople would find uncongenial and burdensome even a relaxed form of the religious life, 'as easy as we call it, and as wealthy too'. ${ }^{84}$

\footnotetext{
${ }^{79}$ Ibid., VI, pp. 296:25-297:2, VII, p. 153:1-11, IX, p. 49:16-28.

${ }^{80}$ Ibid., VI, pp. 87:8-88:7, 92:22-94:5. More also referred in this work to a scandal in Berne, where certain friars were burned for alleging false miracles: VI, p. 88:31-4.

${ }^{81}$ Aside from More's Merry jest, the first book of Utopia features a pompous and humourless friar: ibid., IV, pp. 82-5.

${ }^{82}$ Ibid., X, p. 46:11-21, VI, p. 83: 18-35, VII, p. 207:17-24.

${ }^{83}$ Ibid., VI, p. 427:32.

${ }^{84}$ Ibid., IX, pp. 67:30-68:7, 82:33-83:29.
} 
Thomas More's polemical defence of the religious orders of his day therefore comes across as ambivalent and guarded. He may have felt the need to exercise some caution when drafting the Apology, which attacked a treatise that has been described as 'the king's secondary propaganda'. ${ }^{85}$ Yet, the Henrician regime had not at this juncture embraced any overt anti-monastic agenda, such as might have caused More to tread carefully when discussing the religious orders in general, either in the Apology or in his anti-evangelical polemics. The most plausible explanation therefore for his reluctance to offer a full-throated apologia for the religious orders of Henry VIII's England, in the face of fierce evangelical and anticlerical attacks, is his own personal reservations about general standards. As we have seen, More was swift to praise that (numerically small) branch of the regular clergy in early Tudor England associated with strictly observant reform. However, his voluminous writings at no point offer explicit commendation of any other religious houses or orders, while disclosing hints of wider unease. As we have seen, the 'Letter to a monk' dismissed the 'conventual' Franciscans as unreformed and neglectful of their founder's rule. More's ringing praise of the inherent value of monasticism in his 'Letter to Bugenhagen', cited above, also drew a stark distinction between saintly and worldly manifestations of the religious life. The full quotation reads:

Religious orders have produced a great many men of extraordinary sanctity. Although some monks have not always lived up to their order and some orders have degenerated to the behaviour of the world around them, nevertheless the purest segment of the Christian people have always been found in religious orders. ${ }^{86}$

It is significant that More's critique of monastic worldliness is applied here not just to unworthy individuals, but to entire religious orders.

There is reason to suspect, therefore, that the corollary of Thomas More's enthusiasm for the Carthusians, Bridgettines, and Observant Franciscans was a more critical stance towards the large majority of religious houses in early Tudor England which did not follow strictly observant forms of monastic or mendicant life. Recent scholarship has concluded that these 'mainstream' religious orders retained considerable energy, particularly in their creative interaction with wider society and the secular church. In More's day, they made a notable collective contribution to various facets of popular religion (such as pilgrimage and the cult of saints) and to the development of the polyphonic music pioneered in royal chapels and collegiate churches, while monks and friars were also a prominent presence in the universities. ${ }^{87}$ A vigorous championing of the early Tudor religious orders as a whole might therefore have highlighted activities of these kinds. Thomas More's treatment of such

${ }^{85}$ Guy, 'Thomas More and Christopher St German', p. 112.

${ }^{86}$ CWTM, VII, p. 52:5-11.

${ }^{87}$ See, inter alia, J. Clark, ed., The religious orders in pre-Reformation England (Woodbridge, 2002); J. Clark, ed., The culture of medieval English monasticism (Woodbridge, 2007); Heale, Monasticism in late medieval England. 
outward-looking or 'modernizing' elements of monastic practice, however, was at best equivocal.

More's general defence of pilgrimage and miracles in the Dialogue concerning heresies incorporated the activities of religious houses; but his recounting of several examples of fraudulence and folly at monastic or mendicant shrines projected a rather mixed picture. ${ }^{88}$ Likewise, his response to Tyndale's mockery of contemporary liturgical practices, which More understood as aimed partly at the religious orders, was confined to a reciprocal criticism of his interlocutor's patterns of worship. Since in his 'Letter to a monk', he had himself assailed the elaborate musical arrangements adopted in some monastic settings, and championed 'the sober and serious prayers holy fathers prescribed long ago', this oblique response is understandable. ${ }^{89}$ At no point in his polemical writings did More address the theme of monastic scholarship, with which he must have been well acquainted if he did indeed study at Canterbury College. Yet his criticism in the 'Letter to a monk' of John Batmanson's keenness to participate in learned debate ('you will never be in an appropriate position to lecture the world on combating erroneous beliefs, since you even forswore any care for the world when you entered the cloister') suggests some misgivings regarding the intellectual activities of the monastic orders ${ }^{90}$ From such interventions, we might therefore infer that More was less than enthused by communities of monks that devoted a good part of their energies to engagement with, as opposed to strict withdrawal from, the world.

If Thomas More did indeed nurture reservations about the general quality of contemporary religious life, he would not have been alone among his English humanist confreres in forming such an evaluation of the monastic and mendicant landscape of the realm - an environment in which, uniquely in Western Europe, strictly observant forms of religious life were very modestly represented. The humanist agenda to return ad fontes naturally chimed more closely with a monastic programme focused on the literal observance of original rules, than with one centred around adaptation and modernization. ${ }^{91}$ In his 1532 work in defence of monastic life and vows, The pipe, or tun, of the life of perfection, More's friend Richard Whitford of Syon wrote:

I can not deny but that monastical religion is sore decayed and does daily so continue / I am sorry therefore. Show us (say they) one monastery where the promise of their profession is performed. I can show diverse of the reverend fathers of the observants / the charterhouses / with other. ${ }^{92}$

\footnotetext{
${ }^{88}$ CWTM, VI, pp. 54:4-19, 222:1-35 (neutral or positive remarks), 87:8-88:35, 227:31-229:30 (examples of malpractice).

${ }^{89}$ Ibid., VIII, p. 163:12-21, XV, pp. 258:21-259:6; W. Tyndale, An answere vnto Sir Thomas Mores dialoge (Antwerp, 1531), fo. 5r.

${ }^{90}$ CWTM, XV, p. 262:11-13, 24-31.

${ }^{91}$ See also J. Mixson, 'Religious life and observant reform in the fifteenth century', History Compass, 11 (2013), pp. 201-14, at p. 204.

${ }^{92}$ Richard Whitford, The pype, or tonne, of the lyfe of perfection (London, 1532), p. xxiiii. To this statement, Whitford added a distinctly underwhelming defence of the monastic order in early Tudor England more generally: 'And I might say in true conscience: I have known many
} 
A similar assessment of widespread monastic decay was set out in Reginald Pole's Pro ecclesiasticae unitatis defensione (1536), which depicted the majority of religious orders in England as having 'become entirely unworthy of the authors of their rule of life'. The only mitigation, Pole made clear, was the three saintly orders of the Bridgettines, Carthusians, and Observant Franciscans. ${ }^{93}$ Mindful of the need not to concede overmuch ground to his opponents, Thomas More refrained from articulating such stark and explicit judgements in his English polemics. It may be, however, that privately he would have had some sympathy with this diagnosis.

A final hint of More's misgivings towards the religious orders of early Tudor England can be found in his tendency throughout his polemical writings to switch focus onto the international scene. As we have seen, this included enthusiastic praise for the proselytizing efforts of the Observant Franciscans in the New World. ${ }^{94}$ More repeatedly stressed the baleful effects of the closure of religious houses in Lutheran Germany and elsewhere, indignantly highlighting the loss of 'goodly monasteries', the maltreatment of their inmates, and the desecration of their sites. ${ }^{95} \mathrm{He}$ also returned time and time again to the apostasy and vow-breaking of evangelical ex-monks, friars, and nuns, with marriages (like Luther's) between former religious men and women particularly inciting his wrath. ${ }^{96}$ Whatever lay behind More's fixation with this latter theme, in polemical terms it enabled him to move onto the offensive rather than just to respond defensively and equivocally to evangelical critiques of contemporary monastic standards. We may well suspect that he was more comfortable discussing the enormities committed by and against monks, friars, and nuns in Lutheran Germany than engaging in polemical debates about the quality and character of contemporary English monasticism.

Indeed, when analysing the nature of Thomas More's defence of the religious orders in his polemical tracts written between the mid-1520s and early 1530s, it is important to consider his silences as well as his utterances.

monasteries that have been noted of great negligence in keeping of their rules / and yet in the same places were some that always kept right well both their rule and constitutions.'

${ }^{93} \mathrm{~J}$. Dwyer, ed., Pole's defence of the unity of the church (Westminster, MD, 1965), pp. 253-4. Reginald Pole was, of course, one of the authors of the famous 1537 'Consilium de emendanda ecclesia', which controversially advocated that all 'conventual' (i.e. non-strictly observant) religious orders should be phased out by halting further recruitment: J. Olin, ed., The Catholic Reformation: Savonarola to Ignatius Loyola (New York, NY, 1969), pp. 182-97.

${ }^{94}$ CWTM, VIII, p. 191:10-21. A similar theme was pursued in the writings of Richard Whitford: B. Alakas, "“Closed and kept most surely in religion": piety and politics in Richard Whitford's The pype, or tonne, of the lyfe of perfection', Renaissance and Reformation, 36 (2013), pp. 93-128, at pp. 105-8.

${ }^{95}$ CWTM, VII, p. 99, VI, pp. 370:1-13, 412:14-20, 427:26-428:1, VIII, pp. 483:17-29, 485:9-22, 832:310.

${ }^{96}$ This theme recurs in several of More's works, but with special vehemence and persistence in his Confutation of Tyndale's answer and Apology. For contrasting views of its significance, see A. Fox, Thomas More: history and providence (Oxford, 1982), pp. 142-4; and E. Duffy, "The comen knowen multytude of crysten men": A dialogue concerning heresies and the defence of Christendom', in G. Logan, ed., The Cambridge companion to Thomas More (Cambridge, 2011), pp. 191-215, at pp. 209-10. 
At no time did More advance a sustained case in favour of contemporary religious orders, and nor did he ever set out a robust rebuttal of evangelical attacks on the regular clergy. To some extent, More's episodic and relatively oblique defence of monasticism reflects the character of the works to which he was responding, which attacked the religious orders as one of a number of targets. Yet it may also have reflected a preference to focus on other issues. Early evangelical treatments of the religious orders tended to direct their fire not at the monastic ideal itself but at contemporary abuses against it, polemical ground on which More may not have wished to engage his opponents. In any case, it is clear that the religious orders were rarely foregrounded in his controversialist works, despite More's undoubted and oft-stated respect for the monastic ideal.

In his biography of More, William Roper related an episode designed to illustrate his subject's primacy as a bulwark against heresy. During a meeting of Convocation, datable to the late 1520 s or early 1530 s, a clerical collection was organized with a view to compensating More for his pains in writing polemical defences of the church- ' $\mathrm{t}] \mathrm{o}$ the payment whereof, Roper recorded, 'every Bishop, Abbot, and the rest of the clergy were, after the rate of their abilities liberal contributors' ${ }^{97}$ More resolutely refused this gift, but the willingness of heads of religious houses to contribute generously to the whip-round suggests a widespread recognition of their need for a champion, and also their confidence in Thomas More for fulfilling this role. Yet, if they had hoped for a robust general endorsement of their institutions in his polemical writings in the face of evangelical and anticlerical attacks, they must have been disappointed. More's defence of the religious orders in his controversialist works was both guarded and partial - apparently a product of their author's view that English monasteries were in urgent need of some form of observant-style reform.

\section{IV}

In the light of Thomas More's status as (by some distance) the most prolific and high-profile of early Tudor polemicists writing in defence of the church, his reticence on the subject of contemporary monasteries had wider implications. Not only were evangelical and anticlerical attacks against religious houses only partially rebutted in his own works, but More also exerted some influence over other anti-Lutheran writings in the years preceding the Henrician dissolutions. This can be seen most clearly in another notable and widely disseminated polemical work written against evangelical reformers in the early 1530s: William Barlow's A dialogue describing the original ground of these Lutheran factions (1531). ${ }^{98}$

Thomas More's association with this work has long been established, although its precise nature remains contested. It has been suggested that

\footnotetext{
${ }^{97}$ Roper, Lyfe, pp. 45-8. More himself refers to this offer from 'some good and honourable men' of the clergy in his Apology: CWTM, IX, pp. 47:28-48:2.

${ }^{98}$ A. McLean, ed., The work of William Barlowe, including Bishop Barlowe's Dialogue on the Lutheran factions (Appleford, 1981). See also A. McLean, “'A noughtye and a false lyeng boke”: William Barlow and the Lutheran factions', Renaissance Quarterly, 31 (1978), pp. 173-85.
} 
More himself wrote Lutheran factions - a view which was first expressed by the author of the almost contemporaneous evangelical tract, The supper of the Lord (1533). ${ }^{99}$ This is unlikely on stylistic grounds, but there is good evidence for More's close oversight of the work. It was printed by his nephew and publisher, William Rastell, and so literally had More's imprimatur. The form taken by Lutheran factions - a dialogue, in which one character seeks to disabuse a close acquaintance of his evangelical sympathies-recalls Thomas More's own Dialogue against heresies. Finally, as Richard Rex has noted, More did not deny his authorship of the work in his rebuttal to The supper of the Lord, which may also imply some level of involvement in the project. ${ }^{100}$ A plausible recent interpretation is that William Barlow, the advertised author of the work, was pressured by More to write Lutheran factions in order to secure a pardon following his arrest for evangelical activities. ${ }^{101}$ The precise identity of Barlow is also disputed, but he was probably the William Barlow, Augustinian canon, who later became bishop of St Davids under Henry VIII, bishop of Bath and Wells under Edward VI, and bishop of Chichester under Elizabeth I. There are also grounds for equating this William Barlow with the 'Jerome' Barlow who wrote antimonastic tracts in the late 1520 s. $^{102}$ The content of Lutheran factions implies that Barlow had spent some time abroad with reformers, before returning to England and (temporarily) recanting his evangelical views.

As might be expected from William Barlow's monastic background, Lutheran factions had a good deal to say about the religious orders. The work took the form of a dialogue between William, a disillusioned Lutheran recently returned to London from Germany, trying to win over a friend (Nicholas) who still favoured reformist doctrines. A good part of Barlow's treatise was dedicated to a highly negative account of the Reformation on the continent, with a particular stress on internal divisions among evangelicals and on the threat their teachings posed to the social order. Barlow emphasized the deleterious socioeconomic effects that attended the recent monastic dissolutions in Germany, with the poor deprived of alms and ex-religious decanted into the outside world taking work away from laypeople. He also vilified evangelical ex-monks, friars, and nuns as renegades and apostates who had faithlessly discarded their vocation and vows. ${ }^{103}$ In these regards, Barlow's polemic repeated and amplified Thomas More's criticisms of continental Protestants, as presumably he was commissioned to do.

Another similarity between Barlow and More's polemics was their acknowledgement of, and response to, anticlerical attacks on the secular and regular clergy. Just as More had countered various scathing critiques of clerics, so in

\footnotetext{
${ }^{99}$ McLean, ed., Work of William Barlowe, pp. 178-95; The souper of the Lord (Antwerp, 1533), fo. 26r.

${ }^{100}$ R. Rex, 'Thomas More and the heretics: statesman or fanatic?', in Logan, ed., Cambridge companion to Thomas More, pp. 93-115, at p. 113n.

${ }^{101}$ D. MacCulloch, Thomas Cromwell: a life (London, 2018), p. 188.

${ }^{102}$ See the persuasive and detailed discussion of Barlow's identity set out in A. Brown, Robert Ferrar: Yorkshire monk, Reformation bishop, and martyr in Wales (c. 1500-1555) (London, 1997), pp. 265-83. For a counter-argument challenging the conflation of William with 'Jerome', see McLean, ed., Work of William Barlowe, pp. 169-70.

${ }^{103}$ McLean, ed., Work of William Barlowe, pp. 78-9, 87-8.
} 
Lutheran factions the character of Nicholas voiced a similar challenge. His depiction of the religious orders rehearsed familiar anticlerical and Erasmian themes: rascally friars preaching 'old wives' tales', and idle, gluttonous, and ignorant monks whose services lacked true devotion. However, if More's polemical response to such claims was distinctly guarded, the answer of William Barlow's mouthpiece, William, was positively evasive:

If their wretchedness of living as you say be manifest to all the world, it shall not be so needful for you to declare any further thereof as it will be expedient for me to tell of these new gospellers, whose erroneous wickedness is known to very few here in this region. ${ }^{104}$

Barlow adopted this diversionary tactic throughout his tract, never denying the faults of the regular (or secular) clergy but contending that apostate religious were far worse: 'And as for the worst multitude of priests, monks, canons, friars and other religious persons / I dare compare them with the common sort generally of these new factions. ${ }^{105}$

Indeed, for an anti-Lutheran polemic, there is a strikingly downbeat assessment of the contemporary clergy running through Barlow's text. When Nicholas challenged his friend about his former advocacy of evangelical writings, William admitted that he was in part attracted by Luther's attacks on 'the abuses of popes, cardinals, bishops, priests and religious persons', who had drifted far from the perfection of the early church - 'wherein he [Luther] made no lie though in other things he spared the truth'. He also conceded that many priests, monks, and friars 'should be better occupied than they are'. ${ }^{106}$ Moreover, in a manner again in some ways reminiscent of Thomas More's writings, the treatise's most heartfelt praise of the religious orders concerned the holiness of their original founders (a contention which his interlocutor, like most early evangelicals, freely accepted). ${ }^{107}$

The comparison between Barlow's and More's works, in terms of their 'defence' of the religious orders, is by no means exact. There is little in Lutheran factions which speaks in favour of the monastic ideal. Nor did Barlow point to the strictly observant orders as an honourable and commendable exception to general monastic standards in the realm, in the manner of More, Whitford, and Pole. The sole argument Barlow extended in the religious orders' favour was that they were not as bad as Lutheran apostates, and that the dissolution of monasteries on the continent had made things far worse. ${ }^{108}$ But if Barlow's endorsement of the English religious orders was several degrees more lacklustre even than More's, this did not dampen the latter's enthusiasm for his work (or that of Bishop Stokesley of London, who is said to have 'commanded Barlow's dialogues to be preached of the curates throughout

\footnotetext{
${ }^{104}$ Ibid., pp. 78-9.

105 Ibid., pp. 77, 79-80.

106 Ibid., pp. 70, 87.

${ }^{107}$ Ibid., pp. 81-2.

108 Ibid., pp. 87-8, 121.
} 
all his diocese'). ${ }^{109}$ As we have seen, it is likely that More vetted Lutheran factions prior to its publication, and he wrote approvingly of the tract in his Confutation of Tyndale's answer. ${ }^{110}$ We may conclude, therefore, that More found nothing objectionable in Barlow's treatment of the religious orders in early Tudor England. The polemical ramifications of William Barlow's highly equivocal defence of contemporary monasticism are also worth reflecting upon. Just as Thomas More's controversialist works set out no sustained defence of the religious orders - and as Richard Whitford's Pipe, another key rebuttal of Lutheran attacks on the religious life, wrote of widespread monastic decay - neither did William Barlow's Lutheran factions provide much succour to this beleaguered wing of the church. As the monasteries of the realm faced a crescendo of evangelical and anticlerical criticism in the late 1520s and early 1530s, they conspicuously lacked a high-profile champion.

\section{V}

As with his views on most subjects, Thomas More's position towards the religious orders of early Tudor England was complex and nuanced. His writings on monasticism over the course of his career varied in their emphasis, according to changing circumstances and polemical context. Yet his attitude towards the religious orders of early Tudor England appears to have remained broadly consistent throughout his adult life, and across his early humanist writings and later works of religious controversy. As has been argued above, his 'Letter to a monk' was more positive towards monasticism, and his polemical works less enthusiastic about the religious orders, than appears at first sight. More supported the monastic ideal wholeheartedly, and strongly admired the religious houses in England most closely associated with strictly observant monasticism. He was reluctant to criticize openly other branches of the religious orders, at least in his polemical works; but his misgivings can be inferred from the guarded and partial nature of his defence, from his diversions, and from his silences. The depth of More's concerns, and whether they applied equally to all branches of the 'mainstream' religious orders, is unclear; but he evidently would have favoured the significant extension of strictly observant monasticism in the realm.

If Thomas More's stance towards the religious orders can shed some light on his spiritual tastes, it also carries a wider significance. More was by far the most prolific and influential writer in early Tudor England in the face of evangelical and anticlerical critiques of the church and traditional religious practices. Yet he was no cheerleader for the monasteries of his day. More did mount a defence of the monastic life and its practitioners in his polemical writings, but it was restrained and oblique. At no point did he set out a sustained and robust apologia for contemporary religious orders, in the manner of his defences of (for instance) the veneration of saints, pilgrimage, purgatory, and the Mass. He was also content to endorse and disseminate William

\footnotetext{
${ }^{109}$ John Bale, Yet a course at the Romyshe foxe (Antwerp, 1543), fo. 55r.

110 CWTM, VIII, p. 663:21-8.
} 
Barlow's even less enthusiastic depiction of English monasticism. Other works in support of the monastic life published in early 1530s England, such as Richard Whitford's Pipe, advocated strictly observant reform in still stronger terms than More, to the extent that they openly criticized what they regarded as widespread monastic 'decay'. ${ }^{111}$ As a result, the early evangelical assault on the religious orders of the realm, which reached its peak in the late 1520s and early 1530s - with productions such as Read me and be not wrath, The sum of the holy scripture, The practice of prelates, and The old God and the new ${ }^{112}$ - remained substantially unanswered in print by 'conservative' polemicists in Henry VIII's England. The window in which it was possible to publish a wholehearted and unencumbered defence of the religious orders in the face of these attacks without appearing to criticize the Henrician government would soon begin to close.

It is improbable that Thomas More himself, through his polemical writings, could have impeded the Henrician regime's plans to embark upon a significant programme of monastic suppression in the mid-1530s. After all, More (along with William Barlow) had issued stark warnings about the likely negative social and economic consequences of dissolving religious houses: a viewpoint that came to be quite widely shared within a few years of the suppressions. ${ }^{113} \mathrm{He}$ was, moreover, by no means unique among English humanists in his predilection for strictly observant forms of monastic life, and a concomitant lack of enthusiasm for 'unreformed' religious houses. Nevertheless, the absence of any fervent and prominent champion - able to counter the prevalent focus on monastic and mendicant abuses with a more positive narrative - can be seen as a notable area of vulnerability for the English religious orders, as discussions regarding their future gathered pace in the 1530s. ${ }^{114}$ Recent research has emphasized that the fate of the realm's larger monasteries remained an open question deep into that decade, with wholesale dissolution by no means an inevitable outcome. ${ }^{115}$ Yet with no holistic defence of their contribution to English religious culture and society readily to hand - and any potential programme of strictly observant reform a dead letter after the fall-out from the break with Rome - a cogent pro-monastic response to the rapidly evolving government policies of 1537-9 failed to crystallize. In its absence, the case for monastic preservation would be confined to special pleading on behalf of individual houses, to predictably little effect.

\footnotetext{
${ }^{111}$ See also Denis the Carthusian, The lyfe of prestes (London, 1533), A 4v.

112 'Jerome' Barlow and William Roye, Rede me and be nott wrothe (Strasbourg, 1528); Henricus Bomelius (translated by Simon Fish), The summe of the holye scripture (Antwerp, 1529 and 1535); William Tyndale, The practyse of prelates (Antwerp, 1530); Joachim Vadianus (translated by William Turner), A worke entytled of ye olde god [and] the newe (London, 1534).

${ }^{113}$ See, for instance, Kaartinen, Religious life, pp. 59-61.

${ }^{114}$ See also G. Bernard, The late medieval church: vitality and vulnerability before the break with Rome (New Haven, CT, 2012).

${ }^{115}$ MacCulloch, Thomas Cromwell, pp. 487-92, 509-12.
}

Cite this article: Heale M (2022). Thomas More and the Defence of the Religious Orders in Henry VIII's England. The Historical Journal 65, 922-945. https://doi.org/10.1017/S0018246X21000637 